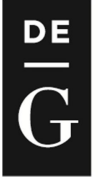

DE GRUYTER

OPEN

DOI: 10.1515/jolace-2015-0014

\title{
Rewriting rural community and dictatorial history through magical realism in Márquez's One Hundred Years of Solitude
}

\author{
Abu Shahid Abdullah \\ Otto-Friedrich University Bamberg, Germany \\ jwl_abdullah@yahoo.com
}

\begin{abstract}
Márquez was greatly influenced by his grandmother's story-telling ability, and was highly indebted to the sociopolitical history of Latin America, particularly Colombia. In One Hundred Years of Solitude, he wants to reconstruct the lost world of childhood by using magical realism which gives expression to the world-view of a rural people who live in isolation from modern world. By retelling the official history from the perspective of the oppressed, he reveals the fact that history is never factual and impartial but serves the interest of those who write it. Through the banana company massacre and the subsequent hide and seek over the number of dead workers, Márquez exposes the way official history becomes fabricated and distorted by authorities, and fails to provide the original occurrences. He was disgusted with the political violence and civil wars which had distraught people; he was also against capitalism, scientific and technological inventions, and so-called modernization, which are the means through which foreign culture brings corruption and brutality, dominates, exploits and oppresses the natives, and threatens the native culture and identity. By employing magical realism, he was able to recreate Colombian history to protest against the way capitalism dominated the socio-political and economic structure of the region.
\end{abstract}

\section{Keywords}

magical realism, capitalism, modernization, solitude

\section{Introduction}

It is a general misconception that all magical realism is Latin American; nevertheless, it must be admitted that Latin America is a crucial location for magical realist writing. The Nobel Laureate Gabriel García Márquez, who is the epitome of magical realism, has inspired many writers all over the globe to employ this mode of writing; he has also strengthened the affiliation between magical realism and Latin American literature. His One Hundred Years of Solitude is an excellent example of magical realist writing, in which the supernatural is presented as ordinary, and the ordinary as extraordinary or magical. According to Warnes (2009), “(....) the novel's magical realism is to be found in its technically brilliant interweaving of natural and supernatural, a style which routinely allows fantastic events to be treated as if they were perfectly normal" (p. 76). Márquez is gifted with an extraordinary ability to blend the mundane with the marvelous, the historical with the fabulous, and psychological realism with surrealism. He carefully balances realistic elements like poverty, sex, massacre, and house-cleaning with magical events like Father Nicanor Reyna's levitating six inches off the ground, Melquíades' return from the death, the canvas sack which contains the bones of Rebeca's parents and makes strange sounds, the strong farts of the characters that kill all the flowers in the house, man who runs through the house balancing beer bottles on his penis, and so on.

Márquez was raised in his grandparents' very big and supposedly ghostly house, situated in Aracataca in the sea-side region of Colombia considered even by the Colombians as an exotic part of the nation, in an atmosphere of superstition. His childhood place became the foundation for his imaginary 
town called Macondo where he set several of his novels, including One Hundred Years of Solitude, and his childhood experience also contributed profusely to the use of magical and supernatural elements and events. Besides his colorful childhood memories, Márquez is highly indebted to the socio-political history of Colombia, for example, the civil war between the Liberals and the Conservatives in the story echoes events similar to the historical events of Colombia. According to Bowers (2004), there are three sources for magical realism in his novels: a confusion of time scales which includes characters having unusual life-span; a mixture of superstition and overstatement which includes incidents when characters are afraid of having child with pig's tail as a result of incest, and when it rains continuously for years; and the antipathy and shock of the new, which includes scientific inventions, brought to Macondo by Melquiádes, and José Arcadio Buendía's amazement after seeing ice and a telescope (p. 40).

Although One Hundred Years of Solitude is, first of all, a comic novel, an entertainment, it is, at the same time, a deeply serious and highly ambitious book that sets out to rewrite the history of Latin America and to offer a view of the human condition (Higgins, 2002, p. 37). Márquez has stated that the prime goal behind writing the novel was to reconstruct the lost world of his childhood. He does so through the mixture of real and fantastic elements that avoids the documentary approach of realist fiction and instead gives expression to the worldview of a rural people who live in isolation from the modern developed world. It should be noted that the magical realism in One Hundred Years of Solitude does not mean that Latin American reality is somehow innately magical, but it does highlight the prodigious scopes of the natural environment and the excesses of political life. The novel presents events not in the way they actually occurred, but as they were noticed and interpreted by the local people.

In order to give a literary depiction of his childhood world, Márquez has created the microcosm of a bigger world in the fictional community of Macondo. The story of Macondo, which is founded by settlers escaping their homeland from the ghost of violence and is born out of a utopian dream, in fact, mirrors the general pattern of the history of Latin America. Macondo thus stands for the dream of a "brave new world" seemingly promised by America and proved illusive by the course of history, and One Hundred Years of Solitude is a demystifying rewriting of the history of Colombia and, in a larger scale, Latin America. The tradition of manipulating history is revealed in the novel when the authorities play hide and seek about the massacre of the banana workers, claiming that in Macondo people leave in peace and harmony. Young Aureliano, who, like his uncle, considers Macondo and its inhabitants the victim of the imperialist and capitalist exploitation of the Banana Company, finds that the high school history books portray the company as a harbinger of prosperity and progress. This novel attempts to expose and ridicule the official myths by providing an alternative version from the perspective of local people dominated and oppressed by outside forces.

In the first place, Márquez raises a voice of protest against the Spanish incursions aimed to colonize Latin America, whereas, in the second, he condemns the North American advances in the South to capture and subsequently make use of the resources of the latter (Ahmad \& Afsar, 2014, p. 4). By retelling the official history from the perspective of the oppressed, he reveals the fact that history never consists of purely factual and impartial accounts, but serves the interests of those who write it. He shows how capitalism, different technological and scientific inventions, and so called modernization are means through which foreign culture brings corruption and brutality, and dominates, exploits, and oppresses the natives. The aim of the article is to prove that magical realism in One Hundred Years of Solitude is employed to create an alternative history by questioning those historical facts which have been included in the authoritative versions of the history of Colombia, to unveil the social and the political problems of the nation and criticize them, and to re-create Colombian history in order to protest against the way capitalism dominated the socio-political and economic structure of the region. 


\section{Intertwining the real and the magical}

Márquez asserts that everything in One Hundred Years of Solitude is based on reality, and he presents those real events not in a realistic way, but through a wonderful mingling of the real and the magical. We find that, in the realm of this novel, beliefs and metaphors become facts, and more common and ordinary facts become uncertain and magical. The main medium for the Márquez's idea of the amazement of reality is his unastonished tone and his refusal of the questions or comments which the state of his culture would seem to require. He took a long time in finding his tone which involves a carefully pitched appearance of gullibility, and adapted it from the examples of his grandmother and Franz Kafka. It enables him to place the historical and the fabulous side by side without conflicting; it does not ask for belief or even a suspension of disbelief, but for something like a suspension of surprise. Márquez needs his tone to establish an unreliable but unquestioned world which is incurably soaked in myth, where legend, hyperbole, metaphor and fact all come to mind as stories coloured in all kinds of ways by need, innocence and expectation. We can look at the description of the death of Amaranta for an example of tone at work. Amaranta is not worried about the time of her death as she already knows it. Death is personified and considered a new character when Amaranta "saw it on one burning afternoon sewing with her on the porch a short time after Meme had left for school. She saw it because it was a woman dressed in blue with long hair, with a sort of antiquated look" (Márquez, 1967/1996, p. 284). She distributes her earthly belongings among the poor, refuses a last confession, and braids her long hair the way she has been told by death.

Several episodes show Márquez's manipulation of language, diction, and narrative to blend the real and the magical elements of his fictional world, the treatment of the mysterious death of José Arcadio being one of them. After returning from the hunting trip, he goes to his room to change clothes, and the very next moment the sound of a pistol shot signals his death and the strange occurrence that follows it:

A trickle of blood came out under the door, crossed the living room, went out into the street, continued on in a straight line across the uneven terraces, went down steps and climbed over curbs, passed along the Street of the Turks, turned a corner to the right and another to the left, made a right angle at the Buendía house, went in under the closed door, crossed through the parlor, hugging the walls so as not to stain the rugs, went on to the other living room, made a wide curve to avoid the dinning-room table, went along the porch with the begonias, and passed without being seen under Amaranta's chair, and went through the pantry and came out in the kitchen, where Úrsula was getting ready to crack thirty-six eggs to make bread (Márquez, 1967/1996, p. 135).

It is also significant when Úrsula reveals that the blood comes from the right ear of the victim, and that no weapon or wound on his body is found. Although José Arcadio's death and its aftermath are not normal, it is made almost realistic by the stylistic accuracy and mundane details that surround the event, such as Úrsula's cracking of eggs.

A quite opposite effect is realized by the account of José Arcadio Buendía's discovery of ice when he goes to the circus with his two sons. He paid extra fee and

(....) put his hand on the ice and held it there for several minutes as his heart filled with fear and jubilation at the contact with mystery.....Intoxicated with the evidence of the miracle, he forgot at that moment about the frustration of his delirious undertakings and Melquíades's body, abandoned to the appetite of the squids. He paid another five reales, and with his hand on the cake, as if giving testimony on the holy scriptures, he exclaimed: "This is the great invention of our time". (Márquez, 1967/1996, p. 18) 
In the previous passage an ordinary object like ice is imbued with an aura of magic by the imaginative, emotion-packed language and wealth of exotic details setting the stage for José Arcadio Buendía's intense reactions to the 'mystery' (McMurray, 1977, p. 90). Márquez's treatment of José Arcadio's death and José Arcadio Buendía's discovery of ice clearly demonstrates his technique of making the fantastic seem real and the real fantastic, thus removing the obstacle between objective and imaginary realities, and creating an entirely fictional world. The role of practical-minded Úrsula lends a note of realism over the extraordinary death of her son whereas her frivolous husband's role in the second occurrence turns an ordinary object ice into an object of wonder which implies that reality is relative, evasive and sometimes contradictory. In dealing with Colombian and Latin American history, and social and political reality, Márquez mingles the natural with the supernatural to show that there is nothing called absolute truth, and that truth is often manipulated by authority.

The depiction of extraordinary people and occurrences is one of the main weapons employed by Márquez to achieve desired effect. Events and personal traits are made larger than life although they remain the logical exaggeration of real situations. When Márquez (1967/1996) says, "It rained for four years, eleven months, and two days" (p. 320), he makes this logical exaggeration purposefully: to underline the severity of the rainstorm that demolishes Macondo. Although such long period of rain is quite unlikely to take place, the exact duration gives the matter a considerable sense of reality; hence, the exaggeration works as an important device to intermingle the extraordinary and exotic with the real.

\section{Resisting political violence}

Márquez, who claims that there is not a single line in One Hundred Years of Solitude which is not based on reality, makes a perfect synthesis of the historical and the fictional world. By placing historical events in a fictional setting, and by treating these events in an unconventional manner through the use of myths and magic, he, actually, wants to create an alternative version of history from the perspective of the people who are oppressed, disempowered, and devoid of any social and political privileges. Since realism is not a suitable to comment on the social and political histories, and to recreate history, Marquez relies heavily on magical realism. He is able to do so because he believes that nothing is absolute and that everything can be challenged, and, through the novel, he tries to prove that the Colombian history can also be challenged. Márquez was disgusted with the political violence and civil wars that swept over Colombia and whole Latin America; he was also against capitalism, imperialism, scientific and technological invention, and so called modernization, all of which he thought to be the means of oppression. By creating a magical and imaginary town Macondo, providing different magical events, dealing with political violence, capitalism and other means of oppression, he, actually, criticizes the real life situation of Colombia and whole Latin America.

One Hundred Years of Solitude is well-appreciated for its social, political, mythical, and epic treatment of Latin America, life-like and imaginary at the same time. Apparently, the novel represents the local history of the fictional town Macondo, the founder of the town 'the Buendías', and the seven generations of it, even thoug the chronicle is the real representation of Colombia and the entire Latin America from its mythical founding to that of the real history, followed by ceaseless civil wars, dictatorship, short revival of democratic rule, massacre, rural violence, and so on. The non-linear time format of the novel is allegorical of the long course of colonization and the way it influenced communal and personal lives of people. The Spanish conquest is represented through the fifteenth century Spanish copper locket and the destroyed sailing ship. Next comes a series of contacts with native Indians and black slaves, and soon begin the civil wars typical for post-independence Latin America. The Americans soon arrive, and represent the modern Western imperialism of the twentieth century. Márquez should be applauded for the historical representation of Macondo. According to Minta (1987), 
His concerns are (...) with the origins of violence, and with the effects that it has on the society in which people have to live. He is thus, inevitably concerned with the whole history of his country and continent, and, both as a writer of novels and as a journalist, he has constantly laid stress on the importance of developing alternative sources of history as a challenge to the status of conventional ones. (p. 3)

Márquez's magical elements derive from the mythology, cultural beliefs, and folklore of his own culture. He has often stated that "his magical realism has come from his grandmother's method of storytelling, and her stories that included folktales and superstitions from their rural region of Colombia" (Williams, 1985, p. 6). In One Hundred Years of Solitude, he includes the rural superstition that an incestuous relationship will give birth to a child with pig's tail, when Úrsula is afraid of the consequence of her incestuous relationship with her husband. Eventually, the superstition comes true when Aureliano, the third child, is born with a tail. By calling Márquez's sources of magical realism a 'village world-view', Salman Rushdie (1991), in his book Imaginary Homelands: Essays and Criticism 1981-1991, means that it is the outcome of a belief system developed in a rural environment, and is one that is little infected by modern scientific explanation (p. 301). Most importantly, Márquez uses this particular technique not only to repeat folkloric mythologies, but mainly to generate a deeper understanding of the destructive present day atmosphere of political corruption. As Rushdie (1991) again comments,

"The damage of reality in South America is at least as much political as cultural. In García Márquez's experience, truth has been controlled to the point at which it has been ceased to be possible to find out what it is. The only truth is that you are being lied to all the time." (p. 301)

Many critics have explored the ways in which One Hundred Years of Solitude records Colombian and Latin American history, with various characters and events based on real life characters and events. Márquez approaches history with a tormented consciousness that official history is tragically inadequate to understand the bloody history of Colombia. According to Warnes (2009), the association between faith-based (magical realism as representation of a provincial world-view) and irreverent magical realism (magical realism as deconstruction of the processes of narrativization) can be seen in the light of one of the most important episodes of the novel: the massacre of the banana company workers (p. 91). Márquez's description of the banana workers and their horrible mass murder is drawn directly from the real events that took place between Colombian government forces and United Fruit Company strikers in Cienaga, a Colombian town, in 1928. Being dissatisfied with their strange payment system, and insufficient medical and sanitary facilities, the workers in the novel appealed to the local authority but after getting no justice they moved to high court which, being bribed by the powerful banana company, turned a deaf ear to their petition. Having no other way they decided to launch a protest which ended in a tragic event of death of thousands of workers.

After the massacre was over a conspiracy of silence was created over the event, particularly about the number of dead bodies. This is one example of the insufficiency of history written in a hierarchical world in which the oppressors write the history of the oppressed through distortion and fabrication. The authority establishes a fabricated version of history and uses it as a powerful weapon to destroy the identity of the native people. Márquez fictionalizes the event where José Arcadio Segundo is considered dead although he succeeds to jump off the train and return to Macondo where he finds that people have no memory of the massacre; no one believes his story, including the families of the dead and of the missing people, and the whole event of massacre is turned into a myth of which people are not at all interested. The authorities have given their official accounts of the events which intend to hide cruelty, and the town people have accepted the lie of the government that no massacre took place. 
Every time that Aureliano mentioned the matter, not only the proprietress but some people older than she would repudiate the myth of the workers hemmed in at the station and the train with two hundred cars loaded with dead people, and they would even insist that, after all everything had been set forth in judicial documents and in primary school textbooks: that the banana company had never existed (Márquez, 1967/1996, p. 396).

This is a very good example of the way official histories manipulate facts and reality, when the government made every possible attempt to block information from the public and pacify the foreign plantation owners. This official history excludes the sufferings of the poor, and creates a sense of social, historical and political dominance. Here, Márquez is playing with the concept of denial by taking it to an extreme level where it is turned into complete ignorance. He employs magical elements to show the manipulation of reality by the authority, and creates and emphasizes an alternative one. He also depends on the use of nostalgia or memory as a means of rewriting the history of those who are oppressed and helpless in a world where the creation and representation of history has been dominated by authoritative figures. Only José Arcadio is conscious of such a deliberate manipulation of events, and the sole believer Aureliano becomes the essential figure in showing the relationship between the massacre, its subsequent suppression from historical memory, and the decline of Macondo. For Saldivar, this episode confirms the extent to which Márquez is preoccupied with "showing the limits of historical discourse" by "showing how historical, governmental and news media discourses are constructed" (cited in Warnes, 2009, p. 91). Márquez defamiliarizes the notion of official and continuous historiography; his most powerful instrument in executing this task is magical realism, and the most direct object of criticism is impermanence itself.

Márquez has come from an extremely traumatized country, Colombia, and has given accounts of long lasting civil war, such as the 'War of A Thousand Days' (1899-1902), and the oppression of government known as 'La Violencia' (1948-1958). In his writing, he shares a troubled historical past, featured by violence and exploitation, triggered by colonialism, cultural and political marginalization, and the results of industrialization and technological development. Although some critics argue that his novels have lost the political power because of the quest for memory and the captivating eccentricity of blending the magical with the real, most other find that magical realism is a strong form of indirect political resistance. To Márquez, it is a way to express the violence, chaos, trauma and confusion of Colombian, and, in a wider sense, Latin American politics. In his Nobel Lecture, The Solitude of Latin America in 1982, he illustrated "how the horrific past and present of much of Latin America lends itself to magical realism due to its ability to convey the unearthly tidings of Latin America" (cited in Bowers, 2004, p. 39).

Because of the technological and social changes accompanying modernization, Macondo turns into a cosmopolitan city, and although increased traffic through the town brings prosperity, it also brings some horror associated with capitalism. We find that the town is changed by the interference of the government; the clash between José Arcadio Buendía's more democratic style of government, and the rules and regulations brought in by the magistrate mirrors a political agenda that is very typical of Latin America. His Macondo, which is most probably a utopian representation of a communist society, is eventually entangled in an uprising against a dictatorial government. We come across the imminent war between the Conservative government in Macondo led by Don Apolinar Mascote and the mutinous Liberals where Aureliano Buendía leads his town people and conquers the town, although later the Conservatives start to rule the land by bringing armed soldier. The attempt to regain the lost innocence of Macondo by defeating the new leader makes things worse; for instance, José Arcadio's mutiny against the government of Don Apolinar Moscote ushers in a worse dictatorship. Through José Arcadio's dictatorship, Márquez shows his dissatisfaction and disgust with this kind of government, and criticizes the dictatorial regimes in $20^{\text {th }}$ century Latin America. We should also keep in mind that it is the corrupt Conservatives who allow the foreign investors to invest in Macondo, and facilitate the rise to the power 
of these foreign imperialists who, by bringing capitalism and modern luxuries, exploit the natives and, ultimately, destroy their lives and the town as well.

For much of the novel, Macondo is afflicted by the civil wars between the Liberals and the Conservatives, which was typical of the nineteenth century Colombia and other Latin American countries, and the futility of that bloodshed is conveyed by the progressive disillusionment of Colonel Aureliano Buendía, the champion of the Liberal cause (Higgins, 2002, p. 42). The character of Colonel Buendía is portrayed partially based on the character of Liberal leader General Uribe Uribe who was highly admired by Márquez's grandfather. As it is pointed out by Minta (1987), both heroes in fact lost all their wars and yet maintained an aura of glory (p. 14). Through the character of Colonel Buendía, Márquez criticizes the ceaseless and needless warfare between the political groups that has marked the violent history of Colombia. He reveals that the differences between the two military groups are so slight and silly that even Aureliano Buendía fails to perceive them. The Liberals are as abusive of power as the Conservatives; as the Governor, José Arcadio Buendía abuses his power and behaves like a tyrant. The legitimization of the second José Arcadio's rights over the land he has usurped in exchange for the right to impose taxes, which is later authorized by the Conservatives as well, exemplifies and strengthens the traditional pattern of oligarchic control. "Márquez also reveals the haphazard and fervent way in which people choose their political allegiances without regard for the political debates, which leads to disastrous and violent consequences" (Bowers, 2004, p. 42)

Aureliano decides to become a Liberal, being convinced on the ground that they wanted to recognize illegitimate children, and, ultimately, devotes a large part of his life to fight for the Liberals. Committed to radial reform, he finds that he is not only fighting the Conservatives but is also at odds with his own party, and finally realizes that they are fighting not for social change but for power. In the later part of his life he realizes, "He had had to start thirty-two wars and had had to violate all of his pacts with death and wallow like a hog in the dung heap of glory in order to discover the privileges of simplicity almost forty years later" (Márquez, 1967/1996, p. 174). This is a wonderful criticism not only of politics but also of human psychology; how easily people get convinced to fight others, and at the end of the day find that they are actually fighting needlessly and uselessly, although by the time they realize it, it is very late. These political violence and civil wars are essentially related to solitude, the central theme of the novel, because after realizing that he has wasted the most precious moment of his life by fighting wars, Aureliano withdraws himself to his workshop and plunges into solitude. It is also suspected that his attempted suicide reflects his despair after realizing that the war is useless, and that pride is the only thing that keeps both sides fighting. "And only two generations later the last surviving Buendía discovers that the colonel's heroic exploits during the civil wars have been erased from the collective memory of Macondo" (McMurray, 1977, p. 82).

\section{Criticizing Capitalism and Oppression}

One Hundred Years of Solitude represents history in two different ways: the way the characters come in touch with it, and the way it actually takes place. Since the characters are trapped between the present and the past, from their standpoints everything is repeating cyclically. A group of people led by José Arcadio Buendía established the town Macondo which is exposed to external world only after the arrival of magical gypsies led by Melquíades. The paradise soon faces the 'insomnia plague' carried to the town by two Indian servants who are the symbolic representation of all the Indian population in America trodden on and oppressed by the dominant Spaniards. In the most general terms, the insomnia plague represents the loss of both political and social recollections, of language, identity, and reality. "The arrival of insomnia plague in the House of Buendía stands symbolic for the deliberate attempts of the governmental authorities to erase the local culture and ways from the collective memory of the Colombian nation. Through the insomnia plague episode, the author registered his protest against the manipulated version of history" (Ahmad \& Afsar, 2014, p.12). Magical realism, which is regarded as a dominant form of political resistance, plays a significant role in creating an example of protest in the 
shape of insomnia plague. The people of Macondo protect their past through writing, attempting to hold onto their consciousness of the surroundings and, therefore, their past, which is also a protest against the oppressive authority. It is only when Melquíades comes back magically from death, like a 'deus ex machina', with a magic potion, that the memory is restored.

"If the story of Macondo reflects the general pattern of Latin America's history, it also reflects the evolution of Western civilization and the progressive alienation of Western man" (Higgins, 2002, p. 47). The early years of Macondo are depicted as Golden Age and the town itself is an earthly paradise where men live happily, but the fall from the zenith of happiness to the nadir of wretchedness comes with its incorporation into the modern age. Under the influence of gypsy leader Melquíades, José Arcadio is seduced by the fascination for science, and feverishly devotes himself to all kinds of experiments, but his passionate pursuit of knowledge distances him more and more from reality and brings him to a state of madness that leaves him completely alienated. Throughout the novel, scientific discoveries execute two functions: science mystifies the citizens of Macondo, and leads to their exploitation. During the search for a utopian world in the second cycle of Macondo's historical time, the town has an increased communication with the rest of the world, bringing civilization, movie-theatre, electricity, running water, and rail-road, which ushered the arrival of US Banana Company. Through the introduction of technology, economic exploitation and foreign incursion, Macondo is transformed into a wonderful modern town from a rustic village within a short period of time. Unfortunately, the arrival of new machines and farming technologies fail to make Macondo a better and more suitable place to live; instead of providing peace, prosperity, and order to the people, situation gets more chaotic. Transportation, in Colombia, has inevitable link to the desire for progress, and the events that would deal Macondo its fatal blow-the strike, the public unrest, the massacre, and its aftermath-take shape at the precise moment when the railway begins to control the events of the novel. Aureliano believes that the railroad was quite essential to modernize his business, and most importantly, to connect the town with the rest of the world, but he fails to understand that the modernity, introduced to Macondo by the arrival of the railway, brings such period of progress which only serves to hide the decline of the true spirit of the town - the Buendía family. The entrance of the banana company is responsible for the destruction of Macondo and its inhabitants which is hinted by the massacre of the banana company workers.

The bringing of modernization into Macondo actually refers to the different real life events of the early $20^{\text {th }}$ century in Latin America, such as the total control of the foreign investors over local resources like sugarcane, coffee, petroleum and so on. "In fact, the story of later Macondo illustrates Latin America's neocolonial status as an economic dependency of international capital, particularly North American" (Higgins, 2002, p. 43). "No sooner had Macondo embarked on a phase of autonomous economic development than it fell under the North American capital and, incorporated into the world economy as a source of primary products, became subject to cycles of boom and recession determined by the fluctuations of the international market" (p. 43). The manipulation of Latin American economy by foreign capital is indicated in the novel by the suggestion that the crisis was created intentionally by the company whose directors were powerful enough to control the weather. The banana company builds houses and colonies which are separated from the local people, and makes a distinct identity. It treats its workforce quite brutally, and Macondo turns into a colony, a company town controlled by company men who are dressed as policemen. The company becomes so powerful that it sends in troops to break the strike by force and to massacre the strikers; the dominant influence of foreign capital in Latin America shows its extension from the economic to the political sphere.

The materialist reading of One Hundred Years of Solitude is probably the most convincing attempt to understand the novel's use of magical realism in the light of the political background of Márquez. "It fits well within the paradigm of demystificatory faith-based magical realism of the kind identified at the end of The Kingdom of This World by Alejo Carpentier where Ti Noel, the protagonist, abandons the attraction of mythical metamorphosis in favor of commitment to the political here and now of this 
world" (Warnes, 2009, p. 84). By showing Macondo's journey from innocence to corruption, Márquez, actually, refers to and criticizes the corruption, instability and violence in the history of Colombia, and, more broadly, of Latin America. He talks about the powerless people who become the victim of this so called modernization. In his own and alternative version of history, this downtrodden people are given a place and voice. Márquez could not show his dissatisfaction and disgust towards Latin American history, politics, and dictatorship in real life, and thus created his fictional stories which, through the use of myth and magic, gave him the opportunity and ability to criticize the established history and to create his own.

In One Hundred Years of Solitude, "Márquez incorporates folklore rather than authorized beliefs from, for instance, organized religion" (Bowers, 2004, p. 43) which makes it possible for the voices of the politically, socially, and culturally marginalized people of Colombia to be expressed and heard. Swanson (2010) notes that Márquez's magical realism:

(....) must be a political question of reinterpretation of reality, utilizing the oral style inherited from his grandmother's fantastic story-telling, García Márquez seems to want to reproduce a traditional, popular rural perspective-challenging the hegemony of the alien, dominant, imported culture and reinstating the value of the community's own cultural perspective (p. 12).

It is quite clear that Márquez was completely against the devastating influence of the foreign culture, and wanted to restore the values of his own culture. He shows the way foreign investors use and oppress the natives; he also emphasizes how the investors bring with them different means of chaos and oppression, such as cinema, luxury items, and brothels, which threaten the indigenous culture and the native identity. For him, the attraction of writing about a place like Macondo is to emphasize the pluralistic story-telling and the story of the downtrodden people rather than the authoritative historical narrative.

As already mentioned, One Hundred Years of Solitude is an attempt to question the historical facts found in official versions of history, and to provide an alternative version. One of Márquez's sources of alternative history is the magical manuscripts of Melquíades, telling the story of Buendía family and of long forgotten people and events in the rural and isolated Macondo. If we look at the narrative structure of the novel, we find there are two approaches to the same story; the history of Buendía family is presented in a chronological order whereas the same events in Melquíades' manuscripts are recorded in a non-linear and fragmented way. According to Merivale (1995), the difference in the treatment of time in the two versions creates a tension in the text between the straight narrative of the family history and the cyclical narrative of the manuscripts (p. 330). This double narrative structure provides the narration with a self-reflexive element by which the reader understands that the narrator is aware of the way the narrative is formed, and according to Sangari (1987), this self-reflexive notion of the novel works along with magical realism to disturb the idea that history is fixed and unchangeable. As Sangari (1987) maintains, '[B]y revealing its constructedness, and making knowledge and truth 'provisional' such novels as One Hundred Years of Solitude revise the history to make it relevant to the present circumstances" (p. 163). By disrupting fixed categories of truth, reality and history, magical realism creates a space between official discourses where the unpresentable can be presented, the inexpressible can be expressed, and the unspeakable can be spoken.

One has to emphasise again and again, Márquez subtly blends the supernatural with the real to depict marginal communities within capitalist economies, and the destruction these economies can bring about. The banana company is nothing but the sign of the invading capitalism and imperialism the Macondians become victim of, and the plight of these suffering people is portrayed through magic. Because of the arrival of new money and new people by the banana plantation, the perfectly ordered Macondo becomes noisy and disordered. Although, apparently, it promises progress and wealth, the banana company takes a heavy toll on the pre-industrial, pre-material, and idyllic village. Because of its 
arrival, Macondo gradually turns into a cosmopolitan town, with the cinema, phonographs, luxury items, and more and more prostitutes making the situation chaotic, uncontrollable, and threatening for the local culture. The United Fruit Company has not only exploited its workers physically, psychologically, and financially, but also attacked the local culture making the natives live in a constant threat of losing their cultural identity. "When progress is achieved at the expense of human rights, when material wealth brings about exploitations and spiritual death, then the foundations of a people or a nation are shattered" (Vega-González, 2001, p. 4). We find Aureliano Segundo's realization of the harmful traces the banana company left behind for the Macondians when he says that Macondo had been a prosperous place and well on its own way until it has been disordered, corrupted, and suppressed by the banana company.

The patriarch José Arcadio Buendía is also criticized for his inclination towards material progress; in his determined but futile attempt to find gold, he decides to use the magnet the gypsies brought into the village. The only things he finds are the traces of Spanish imperialism, which are surely predictive of the new oppression his village will encounter with the arrival and operation of the banana company, and the bloody and cataclysmic occurrences it will bring about between the natives and the army. Unfortunately, José Arcadio is prevented to see further connotations of the Spanish armor he finds because he is blinded by the fierce desire for progress, the technological advancement, and the temptation of enhancement. His initial attitude of collective initiatives, such as the traps and cages to ensure that all the houses in the village would have birds; the placement of houses in such a manner that they all could get same amount of solar energy and river water, is brutally destroyed by his fascination for scientific inventions. As Márquez (1967/1996) says, "However, that spirit of social initiative disappeared in a short time, pulled away by the fever of magnets, the astronomical calculation, the dreams of transmutation, and the urge to discover the wonders of the world" (p. 10). The magnifying glass not only burns him, but also insults him in front of the authorities since his attempt to show its effect on the enemies fails. Because of the frustration arising from his failure in his scientific enterprise, José Arcadio loses interest in life, becomes insane, and spends his last years tied to a chestnut tree in the backyard of his house. Márquez seems to make the reader understand that although science is considered to be miraculous in nature, it has been used as an instrument to subdue people and nations, and it can destroy the very person who is fascinated with it. Thus it could be said that Márquez clearly stands against materialism, capitalism, industrialization and scientific progress, and links them with frustration, solitude, oppression, and the fear of losing identity. In dealing with these issues, however, he heavily depends on the blend of the magical with the real.

\section{Conclusion}

As mentioned above, Márquez has got his story-telling ability and his unastonished tone from his grandmother, the Caribbean and his childhood in a supernatural atmosphere, and was hugely influenced by Franz Kafka and the socio-political histories of Colombia. He collected his magical realist elements from the oral story, local beliefs, rural superstitions, as well as familial and provincial worldview. In this sense, One Hundred Years of Solitude can be labelled as faith-based strand of magical realism which requires the reader to stop disbelieving for re-believing, i.e. to sense reality in a more multi-dimensional way than is common in modern and disillusioned world. The novel's magical realism is the instrument to criticize the corrupt government and political violence. By using this particular instrument, and through the descriptions of the Banana Company massacre and its subsequent hide and seek over the number of dead workers, Márquez doubts and challenges the manipulated official version of history and provides an alternative one from the perspective of the oppressed and the marginalized, and the vivid experience and narrow escape of José Arcadio Segundo. Márquez approaches history with a tormented understanding that official historiography is inadequate to understand the bloody history of Colombia. In the novel, magical realism is thus used to express the voice of the politically, socially, and culturally marginalized or un-represented people of Colombia, and to rewrite their own history. 
Again, by taking a strong stand against capitalism, imperialism, the so called civilization, modern inventions such as movie-theatre, electricity, railroad, farming technology, and different other means of oppression which have threatened native culture and identity and oppressed native people, Márquez seems to have challenged the hegemony of the alien and dominant culture.

\section{References}

Ahmad, M. \& Afsar, A. (2014). Magical Realism, Social Protest and Anti-Colonial Sentiments in One Hundred Years of Solitude: An Instance of Historiographic Metafiction. Asian Journal of Latin American Studies, 27(2), 1-26.

Bell-Villada, G. H. (1990). García Márquez: The Man and His Work. University of North Carolina Press.

Bowers, M. A. (2004). Magic(al) Realism. London and New York: Routledge.

Conniff, B. (2002). The Dark Side of Magical Realism: Science, Oppression, and Apocalypse in One Hundred Years of Solitude. In G. H. Bell-Villada (Ed.), Gabriel García Márquez's One Hundred Years of Solitude: A Casebook (p. 139-152). New York: Oxford University Press.

Hart, S. M. (2003). Magical Realism in the Americas: Politicized Ghosts in One Hundred Years of Solitude, The House of the Spirits, and Beloved. Journal of Iberian and Latin American Studies, 9(2), 116-123. doi: 10.1080/1470184032000171759

Higgins, J. (2002). Gabriel García Márquez: Cien años de soledad. In G. H. Bell-Villada (Ed.), Gabriel García Márquez's One Hundred Years of Solitude: A Casebook (p. 33-51). New York: Oxford University Press.

Márquez, G. G. (1967/1996). One Hundred Years of Solitude. (G. Rabassa, Trans.). Kolkata: Penguin Books India.

McMurray, G. R. (1977). Gabriel García Márquez. New York: Frederick Ungar Publishing Co.

Merivale, P. (1995). Saleem Fathered by Oskar: Midnight's Children, Magic Realism, and The Tin Drum. In L. P. Zamora \& W. B. Faris (Eds.), Magical Realism: Theory, History, Community (p. 329-345). Durham \& London: Duke University Press.

Minta, S. (1987). Gabriel García Márquez: Writer of Colombia. New York: Harper and Row.

Rushdie, S. (1991). Imaginary Homelands: Essays and Criticism 1981-1991. London: Granta and Penguin Books.

Sangari, K. (1987, Fall). The Politics of the Possible. Cultural Critique, 7, 157-86.

Swanson, P. (Ed.). (2010). The Cambridge Companion to Gabriel García Márquez. UK: Cambridge University Press.

Vega-González, S. (2001). Memory and the Quest for Family History in One Hundred Years of Solitude and Song of Solomon. CLCWeb: Comparative Literature and Culture, 3(1), 1-9.

Warnes, C. (2009). Magical Realism and the Postcolonial Novel: Between Faith and Irreverence. UK: Palgrave Macmillan.

William, R. L. (1985). Gabriel García Márquez. Boston, MA: Twayne Publishers.

Wood, M. (1990). Gabriel García Márquez: One Hundred Years of Solitude. UK: Cambridge University Press.

\section{Contact}

Md Abu Shahid Abdullah

Department of English Literature

Otto-Friedrich University Bamberg, Germany

jwl_abdullah@yahoo.com 